\title{
CONTEMPORARY PHOTOGRAPHY PRACTICE: FROM LANDSCAPE TO EXPANDED MODES OF PLACE REPRESENTATION
}

\author{
PRÁTICA FOTOGRÁFICA CONTEMPORÂNEA: DA PAISAGEM A \\ MODOS EXPANDIDOS DE REPRESENTAÇÃO DE LUGAR
}

RODRIGO HILL*

rdrgohill@gmail.com

Contemporary photographic practice has evolved into a broad field of possibilities, a flux of representational modes that depict emotions, experiences and feelings. In parallel the depth and layering of places offers a stimulating challenge to researchers and artists whom are willing to creatively explore nuances of land and nature as well as the multi-sensorial and spatial "reality" of places. The Waikato River is my research locale, located in the central North Island of Aotearoa New Zealand. I draw on contemporary photography practice and theory to develop multimodal approaches to my research place, expanding objective modes of landscape and place representation. I trace a timeline from early landscape photography practice particularly during the British colonisation in New Zealand juxtaposing my photography practice as a counter approach to Eurocentric modes of place representation. This is informed by local Waikato Māori cosmologies and more contemporary readings on place. As a result I conceptualised a theoretical framework around the notion of place imaginaries as a creative platform for the development of expanded photographic modalities.

Keywords: Contemporary photography; place; landscape; Waikato River; Aotearoa New Zealand

A prática fotográfica contemporânea evoluiu para um amplo campo de possibilidades, um fluxo de modos representacionais que representam emoções, experiências e sentimentos. Paralelamente, a complexidade e as camadas dos lugares oferecem um desafio estimulante para pesquisadores e artistas que desejam explorar criativamente as nuances da terra e da natureza, bem como a "realidade" multissensorial e espacial dos lugares. O Rio Waikato é meu local de pesquisa, localizado na região central da Ilha Norte de Aotearoa, Nova Zelândia. Eu me baseio na prática e na teoria da fotografia contemporânea para desenvolver abordagens multimodais para o meu local de pesquisa, expandindo modos objetivos de fotografia de paisagem e representação de lugar. Eu traço uma linha do tempo a partir da prática inicial da fotografia de paisagem, particularmente durante a colonização britânica na Nova Zelândia, justapondo minha prática fotográfica como uma contra-abordagem aos modos eurocêntricos de representação do lugar. Isso é informado por cosmologias locais Waikato Māori e leituras mais contemporâneas sobre teoria de lugar. Como resultado, conceitualizei um referencial teórico em torno da noção de imaginários de lugar como uma plataforma criativa para o desenvolvimento de modalidades fotográficas expandidas.

1* Rodrigo Hill, Phd, University of Waikato School of Arts. Whaingaroa Raglan, Aotearoa New Zealand. ORCID: 0000-0003-3943-0393 
$168 \mid$ RODRIGO HILL

Palavras-Chave: Fotografia contemporânea; lugar; paisagem; Rio Waikato; Aotearoa; Nova Zelândia.

Reception date: 09-06-2021

Acceptance date: $12-10-2021$

DOI: $10.21814 / 2 \mathrm{i} .3455$ 


\section{Introduction}

In this article I draw key ideas from my Practice-led $\mathrm{PhD}$ thesis titled: Place Imaginaries: Photography and Place-making at Te Awa River Ride (Hill, 2019). In the thesis I examined how photography is used as a way to represent place, informing perceptual and place-making processes. Broadly this article develops some of these discussions, highlighting the value of contemporary photography practice as an expanded mode of place representation. In addition, I will introduce the concept of place imaginaries and how it underpins my photography practice and the ways I explored notions of place and place-making. Within this context photography may become a practice of place activation, crystalizing multiple place imaginaries.

The article traces a historical timeline with particular focus on the advancements of photography from early landscape to contemporary approaches to place representation. I will review and discuss early colonial landscape photographic approaches more specifically in the North Island of Aotearoa New Zealand. I then progress to more contemporary modes of place representation, focusing on my photography practice and research locale, the Waikato River located in the central North Island of Aotearoa New Zealand. The juxtaposition of these timeline moments will be useful towards a process of visual decolonisation of the Waikato River, moving away from landscape ways of seeing to more nuanced models of place representation informed by local Waikato Tainui Māori cosmologies.

As a photographer and an artist I developed a methodology based on multimodal systems of representation where multiple place imaginaries (Hill, 2019) and views are validated and represented. Photographic place imaginaries are then re worked through processes of curation that resulted in a photography installation titled South of the Rising Sun (Hill, 2018). I start with a brief introduction to my research place the Waikato River. This will be intersected by local Waikato Māori indigenous views and understandings of place as well as late nineteenth century British colonial landscape photographic practices. I highlight the ways local iwi (indigenous Māori tribes) have understandings of the Waikato River based on cultural beliefs firmly grounded in historical relationships with the land and the waters flowing through it. This is the rich terrain I dive into in search of photographic place imaginaries.

I position myself as a Southern Hemisphere qualitative researcher, engaged in creative practice/practice-led, specifically lens-based approaches and modes of photographic representation. Coming from Brasil, I have been living in Aotearoa New Zealand for more than fifteen years and have completed my $\mathrm{PhD}$ thesis at the University of Waikato with support and guidance from Waikato Tainui Māori scholars, colleagues and research participants. The next section will cover a brief introduction to broader indigenous and local Māori views and understandings on place.

\section{The Waikato River: Introduction to Māori Views}

As a starting point, I would like to acknowledge broader Indigenous Polynesian ways of knowing and understandings places, centralising these views as part of nuanced placemaking processes. Author Karin Amimoto Ingersoll (2016) provides key discussions around Indigenous Hawaiian way of knowing based on embodied, sensorial and intellectual relationships with the ocean, relocating ancestral Kānaka (native Hawaiian 
people) knowledge at the centre of place-making processes. Similarly, author KatrinaAnn R. Kapā'anaokalāokeola Nākoa Oliveira (2014) examines the ways Kānaka developed understandings of place firmly grounded on historical kupana (ancestors) accounts and performances. My goal here however is not to provide an in depth review of these works but to acknowledge the growing field of decolonised scholarship (Jazeel, 2012, 2019; Radcliffe, 2017; Smith, 2012) and particularly focused on place and placemaking. This framework is crucial to my practice-led research, providing key theoretical underpinnings for an expanded model of photographic place representation.

There is an ancient Waikato Tainui story about the Waikato River and its origins. The story is of a white dog that leads the way for the healing waters of Tongariro to flow down to Taupiri. In this story, Taupiri was seriously ill, and she sent a servant to the lands of Tuwharetoa for help. The servant had a white dog as a companion and was directed to go south of the rising sun towards the mountain region of Tongariro. The white dog then led the way back for the healing waters of Tongariro to stream down to Taupiri. The story of the white dog is intrinsically connected to the Waikato River and Valley ${ }^{2}$. Kăterina Mataira (1983) recorded the story into the book called The River Which Ran Away. This book was fundamental to my research; it opened up novel ways of perceiving the Waikato River, informing and guiding my photography practice and research methodology.

The Waikato River is the longest river in New Zealand, totalling 426 kilometres. It begins at Nukuhau near Taupō and is fed by a number of smaller rivers and streams as well as lake Taupō, flowing northwest towards Port Waikato and the Tasman Sea (Muru-Lanning, 2016). Figure 1 below depicts a white dog by the Waikato River. This photograph was constructed based on the ancient Waikato Tainui story and actualises further place imaginaries intrinsically connected to the Waikato River and its origins.

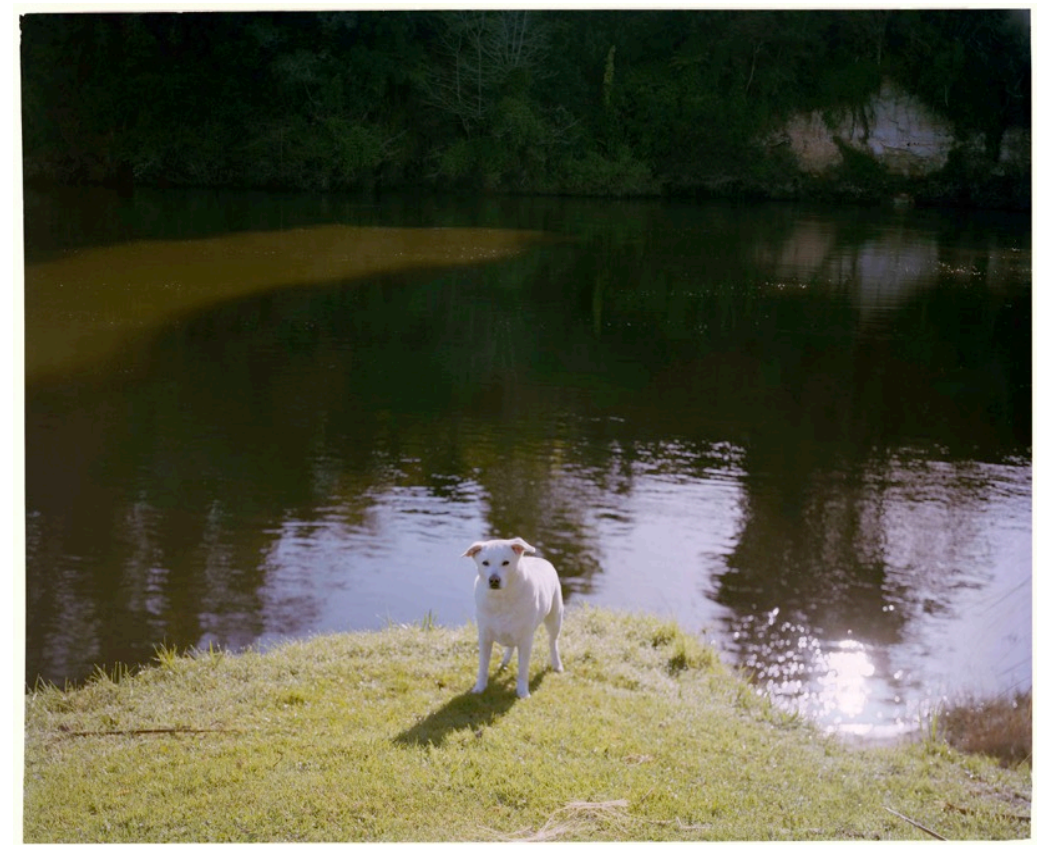

Fig. 1 Rodrigo Hill, The White Dog (2017)

${ }^{2}$ The book The River Which Ran Away is dedicated to the memory of Rore Erueti and Te Uira Manihera of Waikato. According to Katerina Mataira the story from the book “...was related to Te Uira Manihera when he was still young man, by the much loved storyteller of the Tainui people, Rore Erueti. Two years before he passed away, Te Uira Manihera told the story to me" (p. i). 
My focus is to introduce Māori holistic views on rivers and places and the ways tangata (people) and whenua (land) are deeply connected through symbiotic processes of place understanding, identity and belonging. Time, narratives, landscape and ideologies are part of tangible and intangible forms of imaginaries. These position the Waikato River as a bearer of perceptual stories, historical totalities, place layers and imaginaries.

Māori developed rich place understandings by demarcating tribal areas according to geographical features of the land such as mountains and rivers. According to King and Roa (2015), "every tribal group had its own sacred mountain and the significance of the mountains, of the valleys, of the landmarks and the stories the tribe maintained in its relationship to the landmark reflected on the mana (prestige) of the people" (p. 45).

Māori oral traditions are also part of a collection of place understandings; geographic features, such as rivers and mountains, are embedded with a wealth of knowledge and meanings that are represented through legends and stories (King \& Roa, 2015). These processes therefore propose unique ways of perceiving and making sense of the land. Land is then represented via stories that travel through generations and are part of a compelling collection of place imaginaries. Ngāti Wairere historian, consultant and activist Wiremu Puke illuminates this topic further:

We knew how to interpret landscapes because they are embodiments of stories of creation, ancestors and deities, monuments of our past, monuments to our ancestors and their deeds. So the story is an aid to explain an environmental phenomenon. That is often how stories have evolved. (Cook et al., 2011, p. 73)

In addition, whenua is a significant term within Māori culture, used to mean both land and placenta. As Geoff Park (2006) summarises, "Whenua is a product of people living in Pacific ecosystems in which they understood and regarded themselves as tied to the land, water and life around them, as children of a surrounding, sustaining Earth Mother-Papatuanuku" (p. 242). Moreover, the concept of whenua plays a crucial role within Māori views of imagining, understanding, experiencing and making place

In the next section I discuss landscape and colonial photography in the Waikato and the ways photography was used as part of a discursive mechanism to ascertain British imperial ideologies.

\section{Landscape and Colonial Photography in the Waikato}

Contrarily to Māori, European modernist assumptions typically approach land as a commodity (Salmond, 2017). This idea underpinned the British colonial agenda and the invasion of Waikato Tainui territories in the second half of the nineteenth-century. By July 1863 war begun and a number of assaults to the northern areas of the Waikato marked the start of the British invasion and confiscation of Waikato Tainui lands endorsed by the British Crown (Belich, 1986; Boast \& Hill, 2009; Te Aho, 2008). By 1864 the British had proclaimed victory, and most Māori land was confiscated, including the entire territory of the Waikato tribe. In 1995 the Waikato Raupatu Claims Settlement Act offered NZ\$170 million in cash and land as compensation for unjust military action and illegal Māori land raupatu (confiscation) (Boast \& Hill, 2009; Fisher, 2016b, 2016a).

The invention of photography, during the first half of the nineteenth century, was linked with wider objective paradigms and ways of understanding the world. Photographic practices were initially part of a wider paradigm of modernism, assigned 
with making sense of the world through scientific principles of information gathering, mostly observational (Kossoy, 2001). Photography's copying and recording capabilities were certainly appealing and, during the $1840 \mathrm{~s}$, the medium of photography became quickly integrated in various projects and ways of making sense of the world. These included colonisation, land surveying, portraiture as well the documentation of landscapes, war conflicts, road constructions and scientific expeditions (Kossoy, 2001; Schwartz, 1996; Schwartz \& Ryan, 2003). The above photographic practices were intrinsically connected to European understandings of place and landscape, as well as an agenda of aestheticisation and consumption of the land.

Historically, colonial photography from 1860 to 1920 offers a crucial starting point for the use of photographic methodologies (Edwards, 2011). During this time, photography was used as a discursive mechanism to generate a particular set of assumptions and perceptions with regard to the colonised societies (Dench, 2011b; Schwartz \& Ryan, 2003). This paralleled with the conceptualisation and the advancements of the term 'landscape' and its implications (Bender, 1993; Park, 2006; Stewart \& Strathern, 2003; Wells, 2011).

The term landscape was initially introduced as a technical word used by artists and thereby taken up to describe artistic representations of land scenes (Stewart \& Strathern, 2003). Landscape as an artistic genre, more specifically painting, emerged in the west towards the end of the fifteenth century as a backdrop for biblical or mythical stories. During this period the concept of landscape emerged as a 'way of seeing' alongside Renaissance systems of linear perspective as well as the rise of mercantile capitalism (Cosgrove, 1985). According to Denis Cosgrove (1985),

landscape first emerged as a term, an idea, or better still, a way of seeing the external world, in the fifteenth and early sixteenth centuries. It was, and it remains, a visual term, one that arose initially out of the renaissance humanism and its particular concepts and constructs of space. Equally landscape was, over much of its history, closely bound up with the practical appropriation of space ... in painting and garden design landscape achieved visually and ideologically what survey, map making and ordnance charting achieved practically: the control and domination over space as an absolute objective entity. (p. 46)

Cosgrove highlights the shift to objectification and the dualism between nature and culture. The idea of landscape as a way of seeing was intrinsically connected with the development of linear perspective and the rendering of three-dimensional spaces into a two-dimensional surface (Cosgrove, 1985). Gunhild Setten (2010) explains further:

The linear perspective provided power to the eye, giving it absolute mastery over space and ultimately uniting science, architecture in particular, and art. The scenic perspective of landscape was materialized in landscape paintings. The "enclosed space" mediated through these paintings brought with it a new notion of authority and control, power and ownership. (p.137).

In parallel, the industrial revolution and the advancements of capitalism reinforced the notion of nature as an objectified commodity as well as a resource to be exploited (Peden \& Holland, 2015; Setten, 2010). The optical technique of linear perspective informed and grounded the steady advances of capitalism through surveying, map making and land charting (Cosgrove, 1985). In addition, "the mathematics and geometry associated with perspective were directly relevant to the economic life of the Italian merchant cities of the Renaissance, to trading and capitalist finance..."(Setten, 2010 , p. 50). European aristocracy during the eighteenth century developed a fashion for the grand vistas. As Wells (2011) explains, "This era witnessed a consolidation of European landscape styles in painting, architecture and, most particularly, landscape 
gardening as aristocracy and wealthy bourgeois families variously commissioned new villas and formally laid out parks and gardens" (p. 28). Wells' point resonates with the nineteenth- century colonial project of British settlers in the Waikato and the inclination for conquering, settling and managing of fertile land territories across New Zealand. Vistas and landscapes were well inserted into the colonial agenda and the construction of places that followed a set of particular social economical patterns as well as aesthetic guidelines.

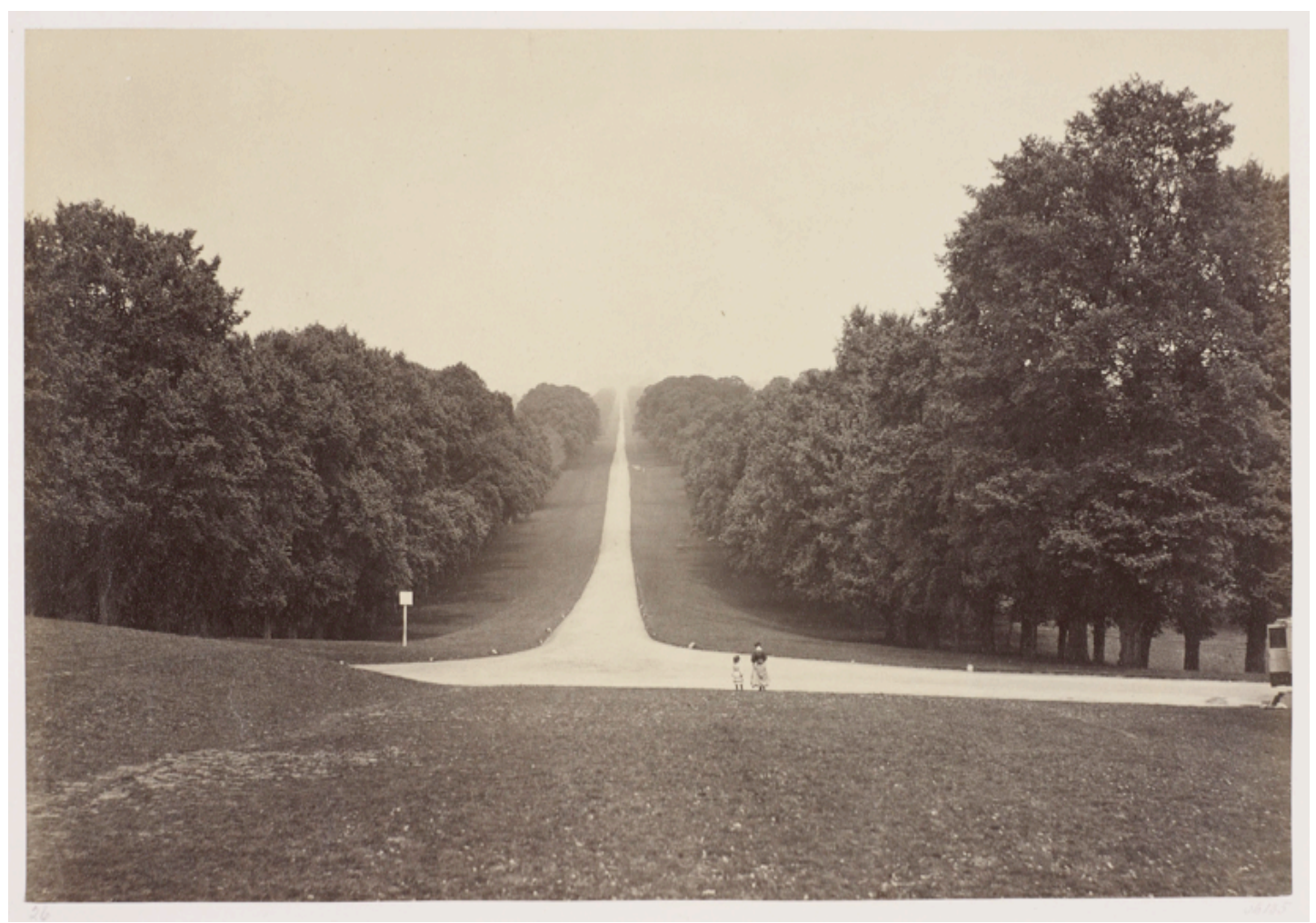

Fig. 2 Roger Fenton, The Long Walk (1860)

Figure 2 is titled The Long Walk, Windsor and was photographed by British photographer Roger Fenton (1860). Wells (2011) contextualises The Long Walk, Windsor with the rise of nineteenth-century royalty and the ways "the commanding view from the house on the hill over its own park reinforced the symbolic status of the owner for whom this (expansive) space was 'my place' (p.29). Coincidentally, this photograph was produced around the same period of time as William Temple's Scene in the Bush and Scene with the Waikato River (Figure 3 below).

My goal is not to compare these photographs but rather analyse the photographer's intentions behind the images as well as the operating discursive contexts of the time. Interestingly, in all photographs there is a concern and focus on the landscaping or taming of the land as well as a kind of celebration of the Imperial achievements. In Scene in the Bush, however, there is an apparent inclination from the photographer to record the "land pioneers" and the taming of the land. On one hand, The Long Walk, Windsor depicts the grand vistas and magnificent gardens of Windsor, and on the other hand, Scene in the Bush and Scene with the Waikato River depict the taming yet to be magnified. Yet all photographs convey a sense of ownership and, as pointed out by Wells, the idea of a particular space as "my place". It is important to note that the technological processes to construct photographs in the 1800 s were very limited and 
involved a lengthy set up. As a consequence, the photographs had to be carefully planned and conceived (Dench, 2011a).

In this sense, I argue that Scene with the Waikato River may possess a more measured angle through the act of land surveying, a form of study of the land to be conquered, reinforcing and ascertaining particular ideologies such as colonisation and ownership. My point, however, is to highlight the tendency of this emerging genre of photography to document the taming of the land (early form of landscape photography), "progress" and achievements of a particular society. This is linked to the ways images such as The Long Walk, Windsor, Scene with the Waikato River and Scene in the Bush "served to maintain cultural values, social beliefs and political relations" (Schwartz, 1996, p. 31) connected to colonialism.

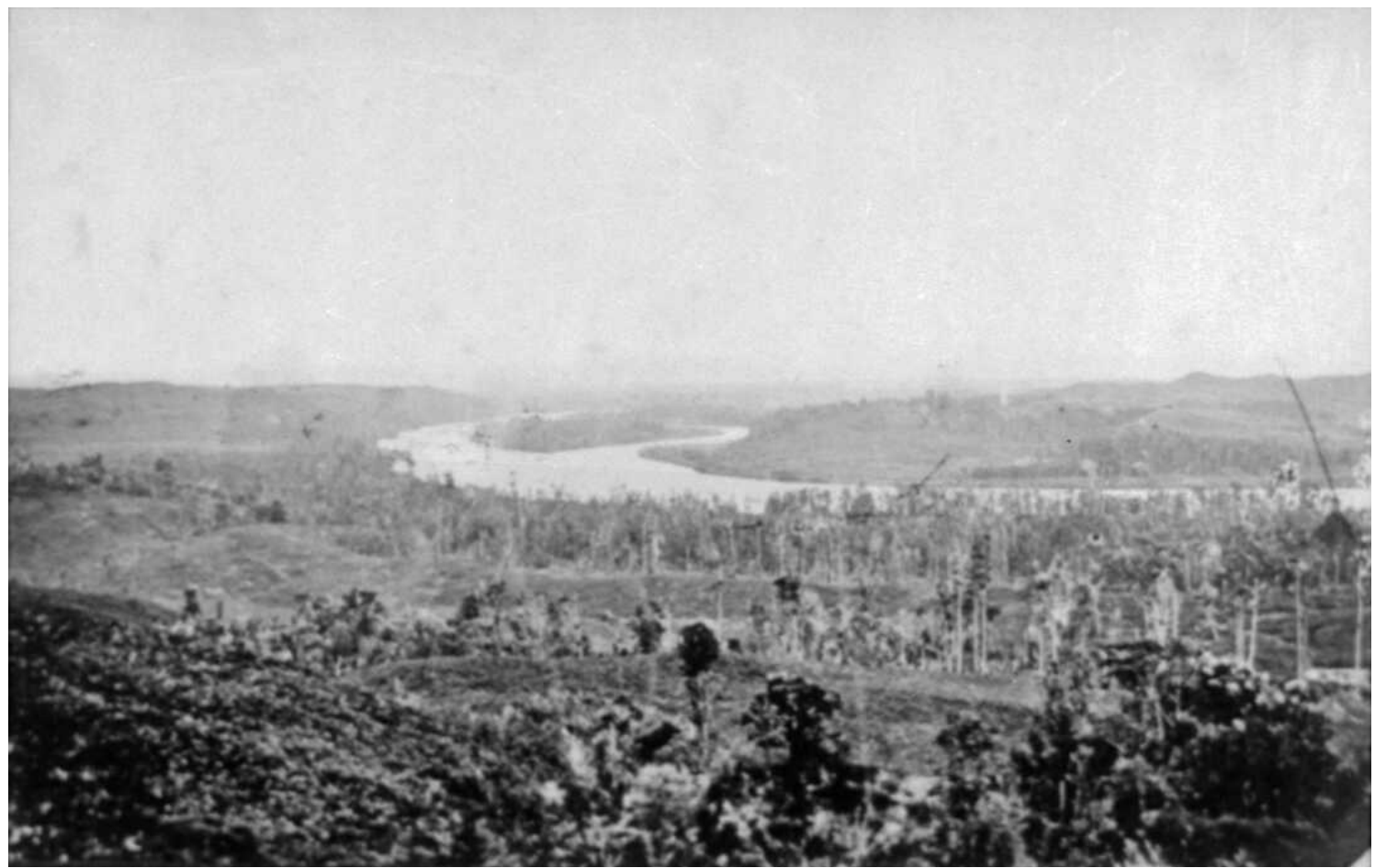

Fig. 3. Temple, William, 1833-1919. Scene with the Waikato River. Urquhart album. Ref: PA1-q-250-42. Alexander Turnbull Library, Wellington, New Zealand. /records/23243408

More specifically related to Scene in the bush and Scene with the Waikato River author Simon Dench (Dench, 2011b) explains the influences of photographic representations during the colonisation of the Waikato region in the latter half of the nineteenth century:

During this period the Waikato was transformed in the region's cultural and physical landscapes and its tangata whenua were subjugated using a variety of strategies, including violent force as well as more subtle forms of coercion. The Waikato was a discursive as well as military battleground and photography was implicated in both of these linked campaigns, as Europeans attempted to claim and justify control over actual and symbolic spaces. (p. 67)

Dench focuses his efforts on investigating the discursive implications of key photographic representations from the colonial period in the Waikato. Dench (2011a) argues that "rather than merely being seen as depictions of place, images can be interpreted as actual sites of colonisation in their production and as artefacts" (p. 33). In addition, landscape photography and cartography were used as mediums to re-present the Waikato within a European model of "seeing" the land (Dench, 2011b) clearly 
attempted in Scene with the Waikato River. In the next section I introduce frameworks around the concept of place imaginaries as a route to expanded modes of place representation and the ways it informs my photography practice.

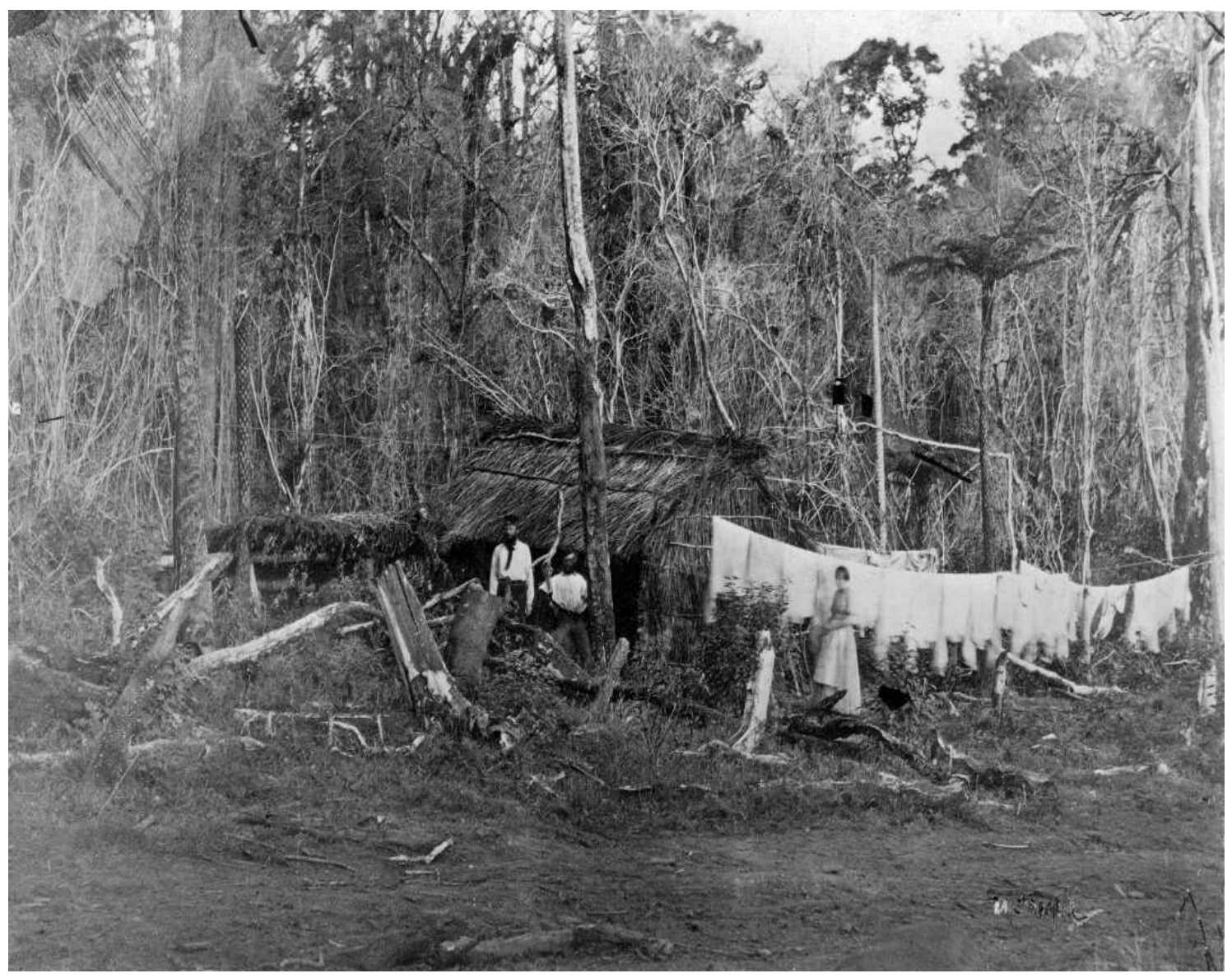

Fig. 4. William Temple, Scene in the Bush Showing a Thatched Hut, Three People and a Washing Line (1860). Source: Ref:1/2-004135-F. Alexander Turnbull Library, Wellington New Zealand. /records/22718238

\section{Place Imaginaries: Relocating Landscape to Place}

Place imaginaries is a multi-layered concept that consists of "a free flowing imagery field between the actual and the virtually perceived" (Hill, 2021, p. 436). I draw ideas from a number of authors from different disciplines including anthropology and human geography in order to explain my concepts of place imaginaries and place-composite. In essence, I understand places as composites of many layers, histories, stories, accounts, views, meanings, cultures and understandings.

Within the discipline of anthropology, it has become common to replace some of the terminologies mentioned above for the term imaginaries (Strauss, 2006). This position relocates place as a more open and fluid concept, a space of circulation of significations and exchanges (Glowczewski, 2012; Massey et al., 2007; Whitridge, 2004). Contrarily to the concept of landscape previously discussed in this article, place refers to more experiential modes of being in the world informed by subjective and collective meanings and significances. On this note Peter Whitridge (2004) adds that: "people do not move through an abstract biophysical matrix, but through meaningful cultural 
landscapes, within socially variable envelopes' (p.243). Whitridge goes further and conceptualises place as

sites of attachment of the real to a space of circulation of socially intangible significations, in which entities that are incommensurate with respect to their materialities-landscape, houses, bodies, thingsfreely exchange properties in the form of conceptual attributes and symbolic associations. (p. 240)

To me, it seems that Whitridge is referring to coalescences or sites of attachment between the 'real' and a collection of intangible significations. These ideas take me back to the Waikato River and my effort to conceptualise it as a dynamic and overwhelming intersection of significations and materialities. These contrapuntal spaces offer me an exciting creative territory where photography can play the role of creating coalescences towards further processes of meaning. My photography practice here functions like a mediator of various perceptual spheres and the passing of specific significations into the material (perceptive) world. Feminist human geographer Doreen Massey (Massey, Allen, \& Sarre, 2007) approaches space as place

as the sphere of juxtaposition, or co-existence, of distinct narratives, as the product of power-filled social relations; it would be a view of space which tries to emphasize both its social construction and its necessarily power filled nature. Within this context, "places" may be imagined as particular articulations of these social relations, including local relations "within" the place and those many connections which stretch way beyond it. And all of these embedded in complex, layered histories. This is place as open, porous, hybrid - this is place as meeting place... (p.18)

I agree with Massey, particularly her point about place as open and hybrid. This is linked with contemporary photography practice and hybrid modes of representing place and land, a flux of representational modes attempting to represent place imaginaries and becomings.

The points discussed above offer relevant frameworks for the expansion of landscape as a concept and practice into more nuanced models where multiple significances are validated. In addition, the ideas discussed above may be linked to nonrepresentational frameworks coined by renowned author Nigel Thrift $(1996,2008)$. Thrift positions our interactions with the world (and place) as part of expanded exchanges at times sensorial, affective, experiential and interactive. Meaning and sensemaking are therefore triggered by these processes and become independent of static representational and discursive structures of meaning (Anderson \& Harrison, 2010). This position is useful to understand the shift from landscape to place or simply the idea that landscape as term and way of seeing long ceased to be static be become a fluid place becoming (Waterton, 2019).

This expansion erodes objective modes of understanding and representing place; it breaks down conventions and fixed views on nature and land by acknowledging surrounding complexities and the play of different forms of cultural knowledge. Within this context the concept of place imaginaries becomes a route to represent visual possibilities and experiential responses to my research locale the Waikato River. These processes are closely connected to my subjective processes of perceiving and understanding the world as well as the ways I use photography practice to represent dimensions of memory and affect connected to place. In the next section I introduce key points related to my photograph practice, unpacking relevant methodological aspects.

\section{Contemporary Photography Practice}


Contemporary photography practice has moved on, as it advanced into a stimulating territory of modalities and fluxes of multiples photographic genres. More specifically, the genre of landscape photography has become infiltrated and infiltrates photographic practices such as photojournalism, documentary and fine art photography. Therefore, it has become harder to pin down photographic genres as photographers now work more fluidly constructing open imagery with multiple points of interpretation (Bright, 2011). In this way the contemporary photographer concerned with landscape aims to move way from perpetuating objective traditions by critically disrupting key representational elements (Kolenda, 2019).

A range of theorists have explored the complexities, politics and meaning of photographic practices and images, and I am particularly interested in Roland Barthes (Camera Lucida, 1980), Susan Sontag (On Photography, 1977), Allan Sekula (The invention of photographic meaning, 1982) and Victor Burgin's (Thinking Photography, 1982) as well as writers John Berger, Teju Cole, John Gossage, Gerry Badger, Abigail Solomon-Godeau, Luigi Ghirri, Joan Fontcuberta and others. In summary, these authors made solid contributions towards a theory of photography in an attempt to "uncover the complex working of the photographic sign system" (Edge, 2013). Renowned Italian photographer and writer Luigi Ghirri (2017) has written extensively about photography and particularly about his Italian landscape works. He argues that the works are more "about the perception of a place than about its cataloguing or description, like some sentimental geography in which the itineraries are not marked and precise but obey the strange confusion of seeing" (p.205). Ghirri's point is valuable and repositions landscape into photographic place-making processes. So perception, feelings and emotions play the role of shaping the photographers gaze, ways of approaching places photographically and the integration of these elements into processes of imagery construction.

Thrift's non-representational framework (1996, 2008) offers again valid underpinnings to expanded and contemporary approaches to photography and landscape connected to affective and sensorial processes of place-making. Building on Thrift, author Emma Waterton argues that landscapes are

not static backdrops, but instead are imagined as fluid and animating processes in a constant state of becoming. Our immediate and embodied interactions with them draw us into equally fluid practices and performances (p.9)

Waterton's point is crucial to understand the ways embodied experiences underpin expanded photographic responses to place, moving beyond objectivity and firmly grounded on feelings and emotions connected to the landscape (Edwards, 2012, 2015). These ideas open up an exciting field of possibilities and modes of place representation positioned within a flux of modalities that, at times, aim to represent the photographer's feelings and experiences. Contemporary landscape photography is well inserted into this context and certainly moved away from objectivity, yet it still operates within core visual conventions, however critically recalibrated and disrupted. I am, nevertheless, not questioning the documentary factor of photographic landscape images and its indexicality. On the contrary, I acknowledge that photographic images do carry traces of the "real" without necessarily having to burden the idea of being truthful representations of the world. In this sense, the indexical aspects of a photograph are only part of a visual vocabulary of expression and "each invites the spectator to actively read the image, and all, variously, implicate questions of subjectivity and identity" (Wells, 2004, p. 283). In the next section I will discuss in more detail how these ideas underpin my photography practice and modes of place representation. 


\section{Photography Practice and the Waikato River: Expanded modes of Place Representation}

My photography practice works within representational fluxes, grounding my artistic efforts towards a multimodal project of photographic representation of place imaginaries connected to the Waikato River. The representational possibilities generated from my photography practice extend previously tested modes of representation common to objective documentary and landscape photography. Within this context, my photography practice becomes liberated from the burden of truthful representation. This shift instigates expanded modes of place representation still undeniably connected to indexical traces and yet capable of generating aestheticised modes en route to artistic expression. As an artist and academic researcher, I am motivated to explore multi representational modalities aimed at unique processes of place actualisation and making.

My photography practice is framed by constructionist assumptions where I create photographic images that represent understandings of the Waikato River located under wider collections of stories, histories, images, practices and particularly the story of the white dog and the creation of the Waikato River. I position myself as a qualitative researcher, beginning with a constructionist epistemology and interpretive research paradigm. I understand photographic practices and images as sources for the construction of multiple meanings. The photographic act, within this scenario, can be argued as a compression of the photographer's intentions and social-cultural contexts.

With the advancements of contemporary photography practice novel approaches to the medium have been considered and post-photography frameworks positioned to locate a number of innovative practices within the medium. As a term Post-photography is still considered a relatively new vocabulary and often problematic to pin down and describe. Curator, photographer and theoretician Joan Fontcuberta (2015) argues that the term post-photography "puts emphasis in the new technological aspect, and in the ontological consequences derived from it"(para 6). On the other hand, author Robert Shore (2014) uses the term post-photography to describe contemporary photographic practices of an artist who works with photography or 'artist with a camera'. Shore's approach relocates the photographer's role to a broader field of practices. Shore (2014) proposes alternative routes for the contemporary photographer-artist: "A new approach to photography is seeing the light-photographers without cameras. The need to press the shutter is replaced by a direct interest in images - not necessarily in making images" (p. 14). For example, the act of capturing images on the computer screen, editing visual archives and giving voice to the material through a process of curation has become just as important as the act of making images. These practices can be linked to contemporary photographic approaches to land and place; and I can locate overlapping elements to my practice such as the aspect of an artist working through conceptual and abstract parameters as frameworks for ones' work. Moreover I highlight the idea of artistic expression and multimodal representation, either working with multiple or no cameras, capturing images from online maps, satellite and other means of representing place.

The multimodal aspect of my practice unfolds through the fusion of photographic genres and use of multiple photographic apparatuses such as digital cameras and film cameras in multiple formats $(35 \mathrm{~mm}, 120 \mathrm{~mm}$ and $4 \times 5)$. Each camera apparatus that I used offered a particular kind of affordance and ways of rendering light. The play of 
different camera apparatuses is a deliberate strategy to suggest the many ways place imaginaries can be photographically rendered and actualised. Place is then photographically represented through paradigms in which 'truth' (place) is understood as a construction of multiple shared 'truths' (place imaginaries) rendered from multiple camera apparatuses.

Figure 6 depicts tree formations from non-native willows by the Waikato River and its banks and were the most intriguing and fascinating to me. Tree branches and whole tree trunks' contorting shapes seemed to be surrounded by a historical aura of mystery. The tree's shapes and patterns offered eloquent visual motifs that I worked through my photographs. Trees that are bending to the weight of time and history, a symbolic act of surrender, yet firmly attached to the roots from a land that never neglected sustenance.



Fig. 6 Rodrigo Hill, Moon rise by the Waikato River, (2017)

The story of the white dog previously introduced in this article informed the construction of particular photographs connected to the Waikato River. The motifs of nature, ecology, movement, light and water were carefully explored through extensive photographic iterations aimed at the construction of a body of work. These iterations were then curated into collections. Part of my methodology consisted of constructing a number of images to be then reworked through editing and sequencing of different curatorial products such as photobooks and installations. The final iterative moment was a photography installation titled South of the Rising Sun exhibited in 2018 at Ramp Gallery in Kirikiriria Hamilton New Zealand and part of my practice-led $\mathrm{PhD}$ thesis. 


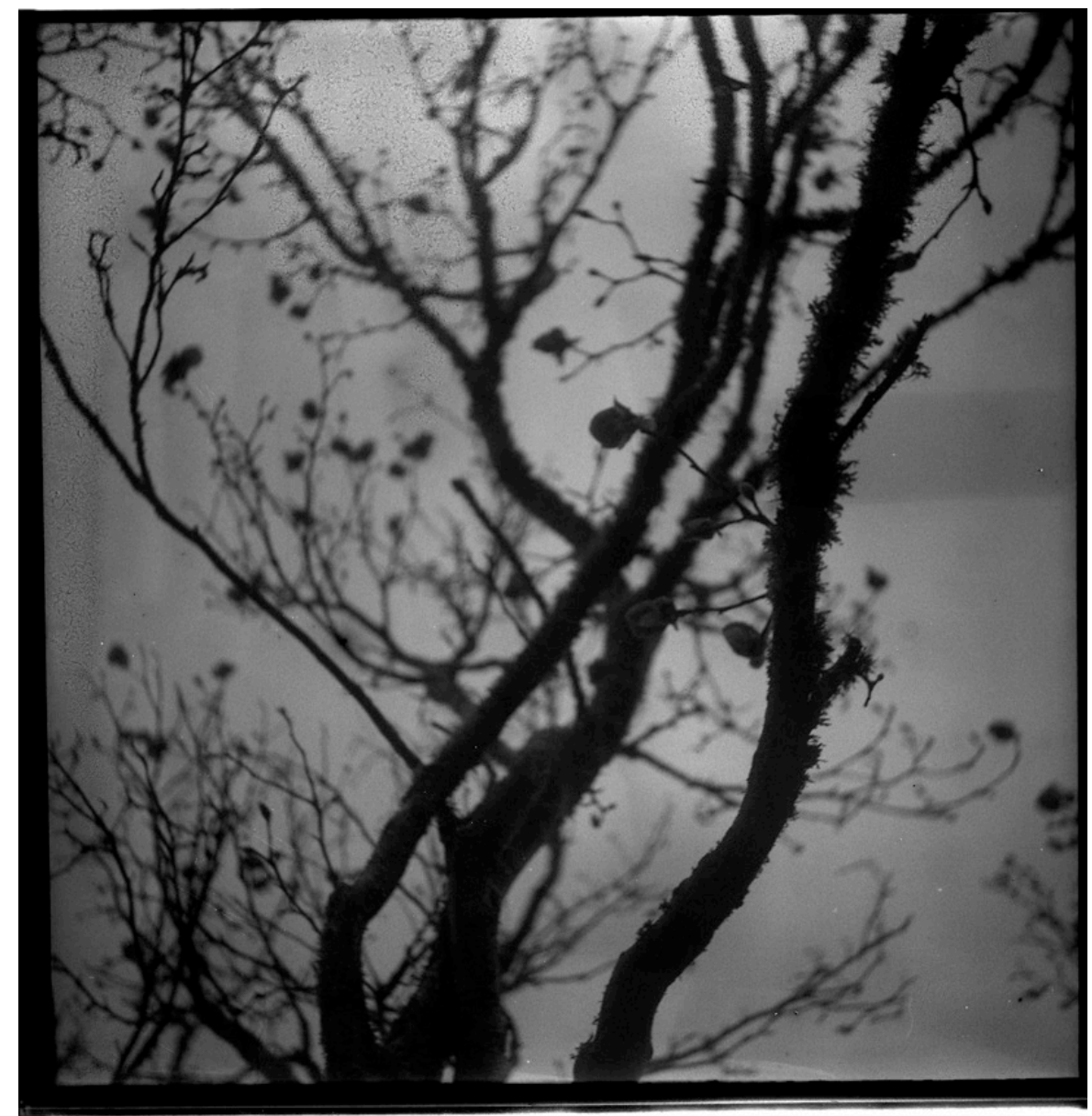

Fig.7 Rodrigo Hill, Blossoming Flowers, Spring (2017)

Figure 7 also represents my interests in trees and contorting shapes as motifs for my photographs. This time I focused on representing the idea of seasonal time passage through the blossoming of particular flowers by the Waikato River. The language of black and white photography offered me more abstract ways of rendering motifs. On this note, philosopher Vilém Flusser argues that black and white photography is abstract and detached from day-to-day life and consequently a useful route to visually represent theoretical concepts (2000). In this sense, black and white photography becomes a powerful tool to create alternative versions of the world that are not primarily connected with our immediate perception capacities. Thereby, when looking at an abstract black and white image one is more prone to be led to a pondering state rather than an immediate chain reaction of recognition.

Similarly, the image below depicts water as an abstract motif, this time my aim, however, was to play and represent some of the healing and spiritual aspects of the Waikato River represented through bubbles of air as a symbol for life. The concept of spiritualty and healing are undeniably connected to the Waikato River and its story particularly when Tongariro offers the waters to be flown down to Taupiri so she could heal from her illness. This provided fascinating and stimulating creative points for me to work on. As an artist I faced challenging processes to represent abstract concepts and in the end I decided to take to the actual waters of the river surrendering to unexpected results from my underwater $35 \mathrm{~mm}$ film camera. 


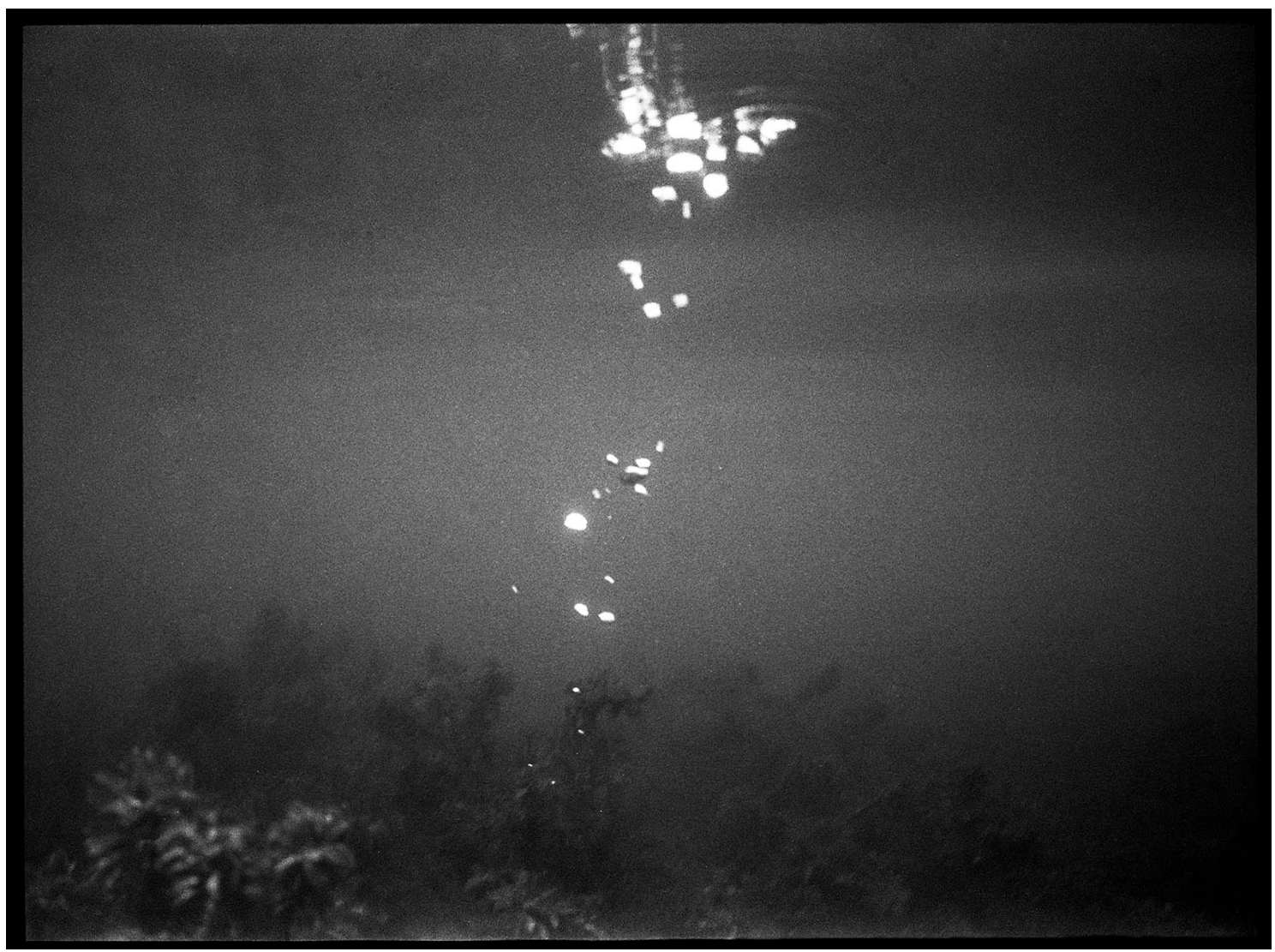

Fig.8 Rodrigo Hill, Waikato te awa (2017)

\section{Conclusion}

This article traced a timeline from early objective modes of photographic representation, particularly colonial landscape photography from the second half of the nineteenth century in the Waikato region in Aoteaoroa New Zealand. I have introduced landscape as way of seeing based on nineteenth century British imperial ideologies. This was connected to ways of making sense of the world thought scientific methods of understanding the world linked with the invention of photography and early photographic practices. Within this context land was perceived as a commodity and photography was use as a tool to reinforce British imperial aspirations and sense of ownership and power over colonised places and societies.

These ideas stand in contrast to indigenous Māori views on the Waikato River and its spiritual and cultural relevancies (King \& Roa, 2015; Muru-Lanning, 2016; Puke, 2011; Te Aho, 2008). Researching European histories of the Waikato Valley, the British occupation, land confiscation and later land settlement processes (Belich, 1986; Boast \& Hill, 2009; Fisher, 2016b; Waikato Raupatu Lands Trust, 2008) contrasted Māori views on the Waikato River and Valley. The British and European ways of conceiving of the land added to colonial and landscape uses of photography constituted the dominant discourses of perceiving and representing places. These European-derived dominant discourses reinforce the appeal and particular ways of perceiving the Waikato River. Through my photography practice, I explored possibilities to open up multiple place imaginaries, coming from a position in which a variety of place imaginaries were recognised and valued. 
The expanded mode of representation I utilised offers a counter-approach to Eurocentric modes of place representation and at the same time validates a range of understandings and meanings attempted photographically. As a result images are more open to interpretation and meaning making processes. The idea of place imaginaries functioned as a theoretical model of perception intertwined with my photography practice and underpinned by the notion of "truth" as a construction of multiple shared truths.

Finally, contemporary approaches to photography offer valid qualitative approaches to visual research. I argue that the leap from European-derived landscape ways of seeing to more nuanced photographic models of place representation must be considered in order to generate further routes to knowledge production and ways of interpreting meanings. Qualitative research approaches to visual research informed by contemporary photography practice allow photographers and visual artists to extend their practices, moving away from the idea of photography as a mere tool to record reality. In this context, qualitative visual practitioners have the opportunity of entering into a stimulating research arena of possibilities where further meanings can be catalysed. I conclude with a visual statement, a photograph depicting a tuna (eel) as part of an underlying collection of stories and imaginaries about the Waikato River and how the river is perceived by Māori as a source of food (Tūrangawaewae Board of Trustees, 2011). Photography here fulfils the quest for an image, an imaginary, a space I dive into in search of place activation.

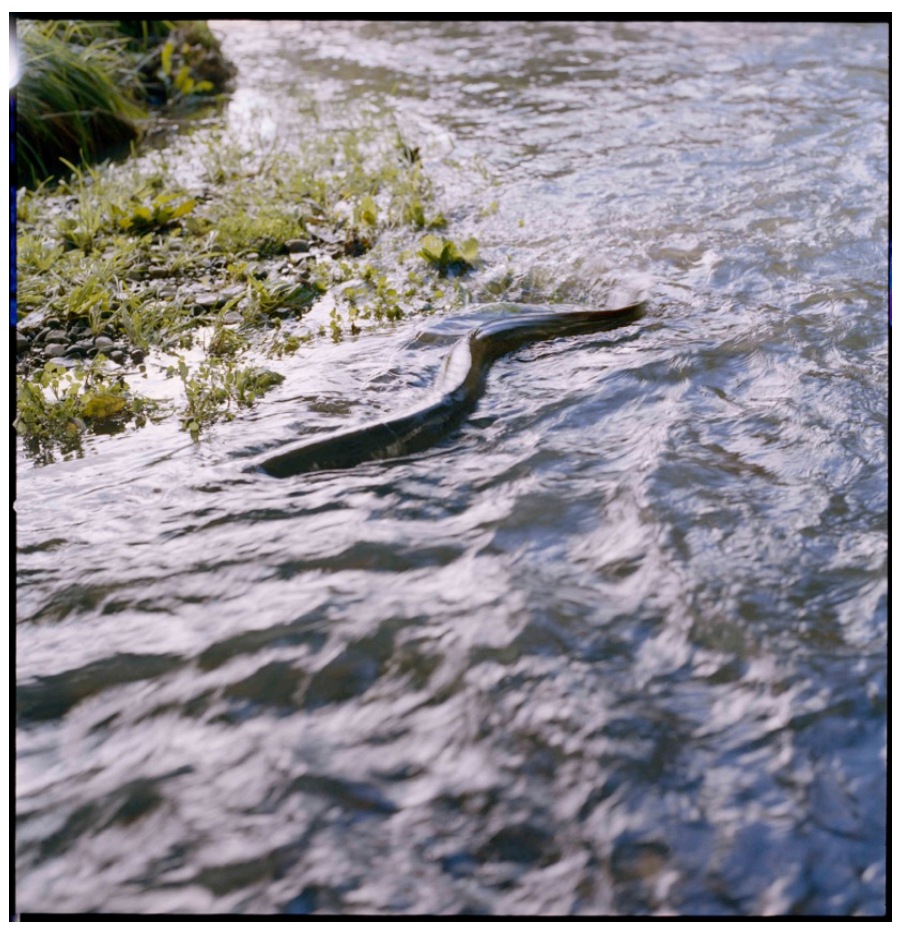

Fig. 9 Rodrigo Hill, Waikato te Tuna (2018)

\section{REFERENCES}

Anderson, B., \& Harrison, P. (2010). The Promise of Non-Representational Theories. In Taking-Place: Non-Representational Theories and Geography: Non-Representational Theories and Geography. Taylor \& Francis Group. http://ebookcentral.proquest.com/lib/aut/detail.action?docID $=539832$ 
Belich, J. (1986). The New Zealand Wars and the Victorian interpretation of racial conflict. Auckland University Press.

Bender, B. (1993). Landscape: Politics and perspectives. Berg.

Boast, R., \& Hill, R. S. (Eds.). (2009). Raupatu: The confiscation of Māori land. Victoria University Press.

Bright, S. (2011). Art photography now (2nd ed.). Thames \& Hudson.

Cook, D. B., Puke, W., \& Valentine, J. (2011). River/road: Journeys through ecology. Rim Books.

Cosgrove, D. (1985). Prospect, perspective and the evolution of the landscape idea. Transactions of the Institute of British Geographers, 10(1), 45-62. https://doi.org/10.2307/622249

Dench, S. (2011a). Invading the Waikato: A postcolonial re-view. New Zealand Journal of History, 45(1), 33-49.

(2011b). Representing the Waikato: Photography and colonisation. Journal of New Zealand Literature, 29(2), 66-88.

Edge, S. (2013). Photography and poststructuralism: The indexical and iconic sign system. In B. Dillet, L. Mackenzie, \& R. Porter (Eds.), Edinburgh companion to poststructuralism (pp. 311-332). EUP.

Edwards, E. (2011). Tracing photography. In J. Ruby \& M. Banks (Eds.), Made to be seen: Perspectives on the history of visual anthropology (pp. 159-189). University of Chicago Press. http://site.ebrary.com/lib/alltitles/docDetail.action?docID=10519583

(2012). Objects of Affect: Photography Beyond the Image. Annual Review of Anthropology, 41, 221-234. JSTOR. http://www.jstor.org/stable/23270708

(2015). Anthropology and Photography: A long history of knowledge and affect. Photographies, 8(3), 1-18. https://doi.org/10.1080/17540763.2015.1103088

Fenton, R. (1860). The Long Walk Windsor [Photograph]. www.royalcollection.org.uk/sites/default/files/collection-online/f/1/4359981387192544.jpg

Fisher, M. (2016a). 'I riro whenua atu me hoki whenua mai': The return of land and the Waikato-Tainui raupatu settlement. Journal of New Zealand Studies, 23, 19-36.

(2016b). The politics of history and Waikato-Tainui's Raupatu Treaty Settlement. New Zealand Journal of History, 50(2), 68-89.

Flusser, V. (2000). Towards a philosophy of photography. Reaktion.

Fontcuberta, J. (2015). The Post-Photographic Condition | Anti-Utopias (S. Bors, Interviewer) [Interview]. https://anti-utopias.com/newswire/post-photographic-condition/

Ghirri, L. (2017). The complete essays 1973-1991. MACK. 
Glowczewski, B. (2012). From academic heritage to Aboriginal priorities: Anthropological responsibilities. Revista de Antropologia Da UFSCar, 4(2), 6-19. https://researchonline.jcu.edu.au/33208/1/33208\%20Glowczewski\%202011.pdf

Hill, R. (2018). South of the Rising Sun / Whakatetonga o te Whitinga o te Rā [Photography Installation].

(2019). Place imaginaries: Photography and place-making at Te Awa River Ride [Thesis, The University of https://researchcommons.waikato.ac.nz/handle/10289/12797

(2021). Contemporary Photography Practice:Expanded Methidology and Critical Ways of Thinking. Design, Art and Technology Journal, 6(2). https://datjournal.anhembi.br/dat/issue/view/16/18

Ingersoll, K. E. (2016). Waves of knowing: A seascape epistemology. Durham; London Duke University Press.

Jazeel, T. (2012). Postcolonialism: Orientalism and the geographical imagination. Geography, 97(1), 4-11. http://www.jstor.org/stable/24412174

(2019). Postcolonialism. Routldge.

Kapā'anaokalāokeola Nākoa Oliveira, K.-A. R.-M. (2014). Ancestral places: Understanding Kanaka geographies. Oregon State University Press.

King, C. M., \& Roa, T. om. (2015). The Maori of the Central North Island before 1860. In C. M. King, D. J. Gaukrodger, \& N. A. Ritchie (Eds.), The drama of conservation: The history of the Pureora Forest, New Zealand (pp. 43-66). Department of Conservation, NZ \& Springer International. https://doi.org/10.1007/978-3-319-18410-4_3

Kolenda, K. (2019). Aestheticising the Post-Industrial Debris: Industrial Ruins in Contemporary British Landscape Photography. Revue LISA/LISA e-Journal. Littératures, Histoire Des Idées, Images, Sociétés Du Monde Anglophone - Literature, History of Ideas, Images and Societies of the English-Speaking World, vol. XVII- $n^{\circ} 1$, Article XVII- $n^{\circ} 1$. https://doi.org/10.4000/lisa.11083

Kossoy, B. (2001). Fotografia \& história (2a edição revista.). Ateliê Editorial.

Massey, D. B., Allen, J., \& Sarre, P. (Eds.). (2007). Human geography today. Polity Press.

Mataira, K. (1983). The river which ran away. Ahuru Press.

Muru-Lanning, M. (2016). Tupuna Awa: People and politics of the Waikato River. Auckland University Press.

Park, G. (2006). Theatre country: Essays on landscape and whenua. Victoria University Press.

Peden, R., \& Holland, P. (2015). Settlers tranforming the open country. In E. Pawson \& T. Brooking (Eds.), Making a new land: Environmental histories of New Zealand (pp. 89105). Otago University Press.

Puke, W. (2011). The Te Araroa Waikato River Walkway investigation report. NaMTOK Consultancy. 
Radcliffe, S. A. (2017). Decolonising geographical knowledges. Transactions of the Institute of British Geographers, 42(3), 329-333. https://doi.org/10.1111/tran.12195

Salmond, A. (2017). Tears of Rangi: Experiments Across Worlds. Auckland University Press.

Schwartz, J. M. (1996). The Geography Lesson: Photographs and the construction of imaginative geographies. Journal of Historical Geography, 22(1), 16-45. https://doi.org/10.1006/jhge.1996.0003

Schwartz, J. M., \& Ryan, J. R. (Eds.). (2003). Picturing place: Photography and the geographical imagination. I.B. Tauris.

Setten, G. (2010). Landscapes of gaze and practice. Norsk Geografisk Tidsskrift - Norwegian Journal of Geography, 57(3), 134-144. https://doi.org/10.1080/00291950310002116

Shore, R. (2014). Post-photography: The artist with a camera. Laurence King Publishing.

Smith, L. T. (2012). Decolonizing methodologies: Research and indigenous peoples (2nd ed). Zed Books.

Stewart, P. J., \& Strathern, A. (Eds.). (2003). Landscape, memory and history: Anthropological perspectives. Pluto.

Te Aho, L. (2008). Contemporary issues in Maori law and society: The tangled web of treaty settlements, emissions trading, Central North Island Forests, and the Waikato River. Waikato Law Review: Taumauri, 16, 229-250. $\mathrm{http} / /$ search.informit.com.au.ezproxy.waikato.ac.nz/documentSummary;dn=6911092579 60927;res=IELHSS

Thrift, N. J. (1996). Spatial formations. Sage. (2008). Non-representational theory: Space, politics, affect. Routledge.

Tūrangawaewae Board of Trustees. (2011). Tōku Tūrangawaewae: Our stories celebrating our 90th year, 12 August 2011. Tūrangawaewae Trust Board.

Waikato Raupatu Lands Trust. (2008). Waikato Raupatu River Settlement: Information package, August 2008. Author.

Waterton, E. (2019). More Than Representational Landscapes. In P. Howard, I. Thompson, M. Atha, \& E. Waterton (Eds.), The Routledge Companion to Landscape Studies (2nd ed., pp. 91-101). Routledge. https://doi.org/10.4324/9781315195063

Wells, L. (Ed.). (2004). Photography: A critical introduction (3rd ed.). Routledge. (2011). Land matters: Landscape photography, culture and identity. I. B. Tauris.

Whitridge, P. (2004). Landscapes, houses, bodies, things: "Place" and the archaeology of Inuit imaginaries. Journal of Archaeological Method \& Theory, 11(2), 213-250. https://doi.org/10.1023/B:JARM.0000038067.06670.34 